\section{Virulence of Viral Hemorrhagic Septicemia Virus (VHSV) Isolates from Japanese Flounder Paralichthys olivaceus in Rainbow Trout and Several Species of Marine Fish}

\author{
Takafumi Ito $^{1 *}$, Koh-ichiro Mori' ${ }^{2}$, Misao Arimoto ${ }^{2}$ \\ and Kazuhiro Nakajima ${ }^{3}$ \\ ${ }^{1}$ National Research Institute of Aquaculture, Fisheries \\ Research Agency, Tamaki, Mie 519-0423, Japan \\ ${ }^{2}$ Kamiura Station, National Center for Stock Enhancement, \\ Fisheries Research Agency, Kamiura, \\ Oita 879-2602, Japan \\ ${ }^{3}$ Headquarters, Fisheries Research Agency, \\ Yokohama, 236-8648, Japan
}

(Received July 22, 2003) analysis ${ }^{6}$. In addition, several properties of these VHSV, including optimal culture conditions, have been reported by Mori et al. ${ }^{7}$. . As epidemiological study found that only Genogroup III was isolated in 1996, and after 1998 , all isolates from Japanese flounder were identified Genogroup I using the polymerase chain reaction method (unpublished data).

In the present study, the susceptibilities of rainbow trout and 4 species of marine fish cultured in Japan, Japanese flounder, black rockfish Sebastes inermis, red sea bream Pagrus major and yellowtail Seriola quinqueradiata to VHSV was examined.

\section{Materials and Methods}

The isolates of VHSV used in this study were JF00Ehi1 (Genogroup I) ${ }^{6}$ and KRRV-9601 (Genogroup III) ${ }^{4)}$ both obtained from farmed Japanese flounder. The virus was cultured using $\mathrm{FHM}$ cells at $20^{\circ} \mathrm{C}$, and stored at $-85^{\circ} \mathrm{C}$ prior to use. Rainbow trout (average body weight: $31.5 \mathrm{~g})$, Japanese flounder ( $16.1 \mathrm{~g}$ ), black rockfish $(14.1 \mathrm{~g})$, red sea bream $(9.2 \mathrm{~g})$ and yellowtail (10.2 g) were used in the study.

Twenty rainbow trout were kept in two $40 \mathrm{~L}$ circulation tanks (10 fish/tank) with a creature filtration system. A dose of $10^{7.5} \mathrm{TCID}_{50} / 0.1 \mathrm{~mL} /$ fish (JFO0Ehi1 and KRRV9601) for experimental fish and $0.1 \mathrm{~mL}$ of MEM for control fish was administered by intraperitoneal injection. Follwing the injection, fish were reared at $12.6^{\circ} \mathrm{C}$ for 35 days. After this period, the kidneys of surviving fish were processed for virus isolation using FHM cells.

Forty Japanese flounder were kept in two $60 \mathrm{~L}$ tanks (20 fish/tank). The viral suspension or MEM was administered by intraperitoneal injection as for the rainbow trout. After the injection, fish were reared at $13.5^{\circ} \mathrm{C}$ for 14 days. Viral antigens in kidney imprints were detected with an indirect fluorescence (IF) test using a polyclonal antibody against VHSV (JF00Ehi1).

For the experiments using black rockfish, red sea bream and yellowtail, each 40 fish were kept in two $90 \mathrm{~L}$ tanks (20 fish/tank). A dose of $10^{7.0} \mathrm{TCID}_{50} / 0.1 \mathrm{~mL} /$ fish (JF00Ehi1) was introduced into all three species by intramuscular injection. The negative control group was injected with MEM. Afterwards, fish were reared for 14 days at between 13 and $15^{\circ} \mathrm{C}$. The virus was isolated from the kidneys of dead fish with FHM cells.

\section{Results and Discussion}

In Japanese flounder, the cumulative mortalities for JF00Ehi1 and KRRV-9601 reached 100\% (Table 1). Hemorrhage in muscle was observed in some dead fish (Fig. 1-a). No difference in symptoms was observed between the fish injected with JF00Ehi1 and with KRRV-9601. Viral antigens were detected in the kidneys of all dead fish using the IF test with antiserum

\footnotetext{
* Corresponding author

E-mail: takafumi@fra.affrc.go.jp
} 
Table 1. Cumulative mortalities of rainbow trout, Japanese flounder, black rockfish, red sea bream and yellowtall infected with VHSV and isolation of virus and detection of IF-positive cells from the kidneys of Inoculated fish

\begin{tabular}{|c|c|c|c|c|c|c|}
\hline Fish & $\begin{array}{l}\text { VHSV } \\
\text { strains }\end{array}$ & of sample & $\begin{array}{l}\text { AV Body weight } \\
\text { (g) }\end{array}$ & $\begin{array}{l}\text { Mortalıty } \\
(\%)\end{array}$ & $\begin{array}{c}\text { Isolation of virus } \\
\text { (No positive/ No tested) }\end{array}$ & $\begin{array}{l}\text { Indirect fluorescence antibody test } \\
\text { (No positive/ No tested) }\end{array}$ \\
\hline Rainbow trout ${ }^{+1}$ & JFOOEhI 1 & 20 & 315 & 0 & $0 / 3$ & - \\
\hline \multirow[t]{2}{*}{ Japanese flounder ${ }^{*-1}$} & JFO0Ehı 1 & 40 & 161 & 100 & -73 & $40 / 40$ \\
\hline & KRRV9601 & 40 & 161 & 100 & - & $40 / 40$ \\
\hline Black rockfish ${ }^{* 2}$ & JFOOEhı 1 & 40 & 141 & 95 & $10 / 10$ & - \\
\hline Yellowtaıl $^{2}$ & JFOOEhr 1 & 40 & 102 & 975 & $10 / 10$ & - \\
\hline
\end{tabular}

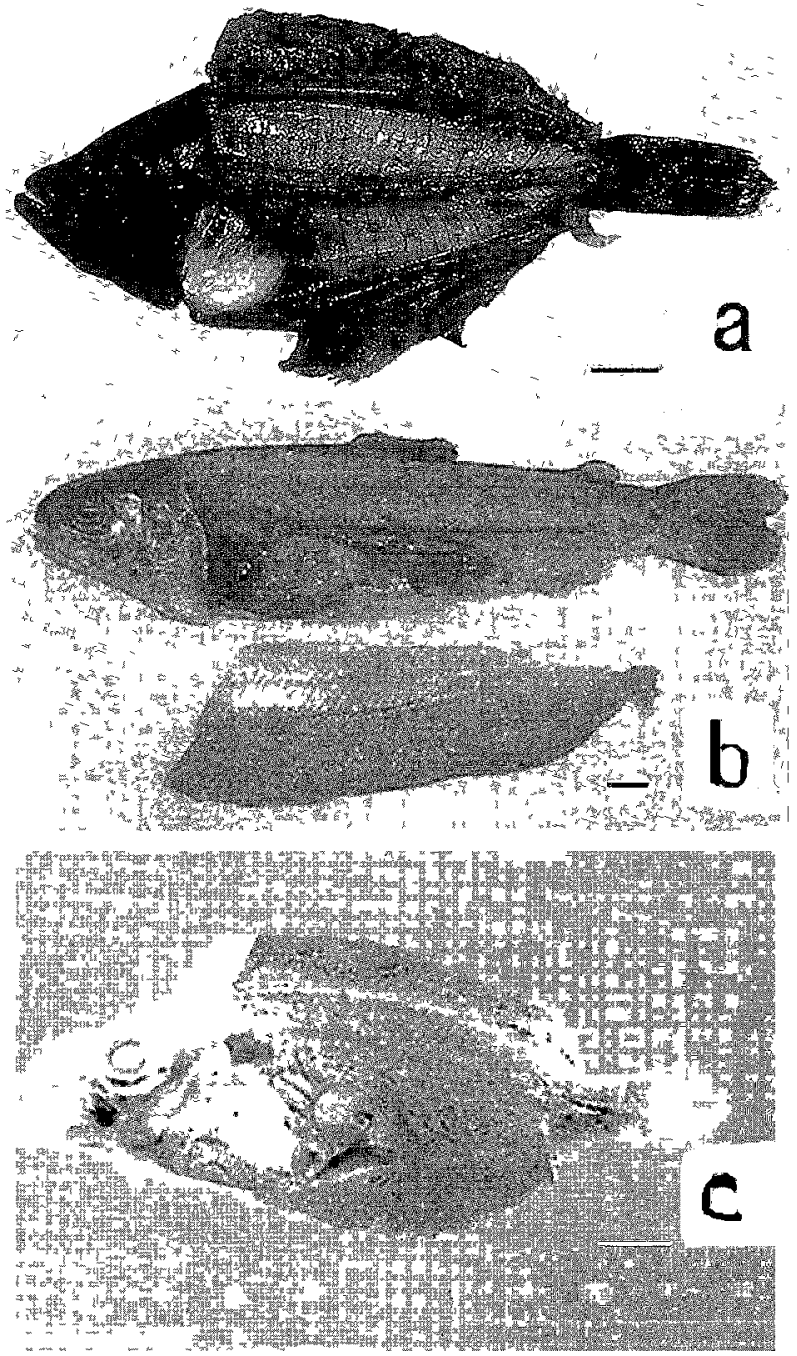

Fig. 1. Experimental fish injected with VHSV JF00Ehı1 Isolate $B a r=1 \mathrm{~cm} \quad$ (a) Japanese flounder showing hemorrhage in muscle, (b) Raunbow trout showing no symptoms, (c) Black rockfish showing hemorrhage in muscle agaınst JF00Ehı1 On the other hand, netther death nor symptoms of VHS such as darkness, exophthalmı or hemorrhagic muscle were observed in rainbow trout Injected with JF00Ehı1 or KRRV-9601 (Table 1, Fig 1b) No histological change was noted in the fish injected with the virus (data not shown) Also, no virus was Isolated from 3 fish examıned at 35 days post-challenge (Table 1) These results indicate that both JF00Ehı1 and KRRV-9601 are little virulent against rainbow trout Snow et al ${ }^{8)}$ reported that the mortality for rainbow trout infected with VHSV isolated from wild Atlantic cod Godus morhua was $10 \%$ VHSV is thought to be of marıne orıgın, and to increase its virulence agaınst raınbow trout by successive passages through the fish ${ }^{9)}$ VHSV-Isolates in Japan have not become virulent for raınbow trout so far We have to seclude Japanese strain of VHSV isolated from marıne fish from salmonids

The cumulative mortalities were 950,750 and $975 \%$ for black rockfish, red sea bream and yellowtal, respectively (Table 1) Diseased black rockfish showed an expanded abdomen due to ascites, and internal hemorrhagIng of muscle (Fig 1-c) Virus was recovered from the kıdneys of all dead fish examined (Table 1) Because marıne fish cultured in Japan are suggested to be susceptible to VHSV, surveillance for outbreak of VHSV infection in cultured marıne fish must be strengthened

\section{References}

1) Small, D A (1999) In "Fish diseases and disorders, Vol 3" (ed by $\mathrm{P} T \mathrm{~K}$ Woo and $\mathrm{D} W$ Bruno) CABI Publishıng, Wallıngford, UK, pp 123-147 2 2) Meyers, T R, S Short and K Lipson (1999) Dis Aquat Org, 38, 81-86 3 3) Kıng, J A, $M$ Snow, D A Small and R S Raynard (2001) Dis Aquat Org , 47, 81-86 4) Isshıkı, T, T Nishızawa, T Kobayashı, T Nagano and $T$ Mryazakı (2001) Dis Aquat Org, 47, 8799 5) Takano R, T Nishızawa, M Arımoto and K Muroga (2000) Bull Eur Ass Fish Pathol, 20, 186-192 6) Nishizawa $\mathrm{T}, \mathrm{H}$ lıda, R Takano, $\mathrm{T}$ Isshıkı, $\mathrm{K}$ Nakajıma and $\mathrm{K}$ Muroga (2002) Dis Aquat Org, 48, 143-148 7) Morl, K, H IIda, T Nishızawa, M Arımoto, K Nakajıma and K Muroga (2002) Fish Pathol, 37, 169-174 8 8) Snow, M, C O Cunningham and I R Bricknell (2000) Dis Aquat Org, 41, 225-229 9) Snow, $\mathrm{M}$ and $\mathrm{C} O \mathrm{O}$ Cunnıngham (2000) Dis Aquat Org , 42, 17-26 